\title{
ANALISIS HAMBATAN SISWA DALAM MENGERJAKAN SOAL BERBASIS KEMAMPUAN PEMAHAMAN MATEMATIS SISWA PADA MATERI HIMPUNAN
}

\author{
Nurtini $^{1}$, Neneng Aminah ${ }^{2}$, Irmawati Liliana Kusuma Dewi ${ }^{3}$ \\ 1, 2, 3 Prodi Pendidikan Matematika, Universitas Swadaya Gunung Jati, Jalan Perjuangan No.1, Cirebon, \\ Indonesia, tininur586@gmail.com
}

Diterima 18 Juni 2019, disetujui 20 September 2019, diterbitkan 31 Oktober 2019

Pengutipan: Nurtini., Aminah, N. \& Dewi, I.L.K. (2019). Analisis Hambatan Siswa dalam Mengerjakan Soal Berbasis Kemampuan Pemahaman Matematis Siswa pada Materi Himpunan. Gema Wiralodra, Vol 10, No 2, Hal 209-219, Oktober 2019

\begin{abstract}
ABSTRAK
Kemampuan pemahaman matematis adalah kemampuan dasar yang harus dimiliki siswa dalam memahami pelajaran sehingga memudahkan siswa untuk dapat mengerjakan latihan soal yang berkaitan dengan materi pembelajaran. Penelitian ini bertujuan untuk menganalisis learning obstacle siswa dalam mengerjakan soal kemampuan pemahaman matematis pada materi himpunan. Sampel dalam penelitian ini adalah siswa kelas VII disalah satu SMP Kabupaten Cirebon berjumlah 39 siswa. Instrumen penelitian ini adalah soal tes uraian berdasarkan indikator kemampuan pemahaman matematis. Hasil penelitian ini menunjukan bahwa learning obstacle yang dialami siswa dalam mengerjakan soal yaitu Siswa belum dapat memahami tanda ketidaksamaan sehingga siswa tidak dapat mengggambar diagram venn, siswa belum dapat memahami cara menggambar diagram venn dalam soal cerita yang disajikan, siswa belum memahami bagaimana proses dalam menentukan jumlah anggota himpunan dari soal cerita permasalahan sehari-hari, dan siswa belum dapat memahami cara membedakan kumpulan yang termasuk himpunan dan kumpulan yang bukan himpunan.
\end{abstract}

Kata Kunci: Hambatan Siswa, Kemampuan Pemahaman Matematis, Himpunan

\begin{abstract}
Mathematical understanding ability is a basic ability that students must have in understanding the lesson so that it makes it easier for students to be able to do the exercises related to learning material. This study aims to analyze students' obstacle learning in working on mathematical understanding abilities on set material. The sample in this study was grade VII students in one Cirebon Cirebon junior high school totaling 39 students. This research instrument is a test item based on indicators of mathematical understanding ability. The results of this study indicate that the learning obstacle experienced by students in working on problems is that students have not been able to understand the signs of inequality so students cannot draw Venn diagrams, students have not been able to understand how to draw Venn diagrams in the story problems presented, students do not yet understand how the process of determining the amount members of the set of daily problem story problems, and students have not been able to understand how to distinguish a collection that includes a set and a collection that is not a set.
\end{abstract}

Keywords: Student Obstacles, Mathematical Understanding Ability, Set

Diterbitkan oleh:

Universitas Wiralodra

Jln. Ir. H. Juanda Km 3 Indramayu, Jawa Barat 


\section{PENDAHULUAN}

Pendidikan merupakan salah satu hal yang dapat menjamin kemajuan sumber daya manusia dimasa depan. Kemendikbud merevisi kurikulum KTSP 2006 menjadi kurikulum 2013 dan sekarang menjadi kurikulum 2013 revisi. Perubahan kurikulum ini diharapkan dapat meningkatkan mutu pendidikan. Matematika adalah ilmu pengetahuan yang sangat berguna bagi manusia dalam melakukan aktivitas sehari-hari. Berdasarkan kurikulum 2013 revisi, mata pelajaran matematika tingkat sekolah menengah pertama memiliki alokasi waktu belajar 5 jam per minggu. Alokasi waktu tersebut harus di manfaatkan secara efektif mengingat matematika merupakan ilmu yang sangat penting. Seperti yang dikemukakan oleh Sundayana (2014: 3), matematika merupakan salah satu mata pelajaran yang mempunyai peranan penting dalam pendidikan. Sehingga matematika merupakan pelajaran wajib dari jenjang sekolah dasar hingga perguruan tinggi.

Salah satu materi dalam mata pelajaran matematika di Sekolah Menengah Pertama (SMP) adalah himpunan. Selain itu banyak konsep-konsep dalam matematika yang dibangun dari konsep tentang himpunan (Sudirman, 2016). Dalam mengerjakan soal-soal himpunan siwa harus mempunyai kemampuan untuk memahami materi agar dapat mengerjakan saol sesuai tahapan-tahapan dengan benar. Kemampuan tersebut adalah kemampuan pemahaman matematis, seperti yang dikemukakan oleh Hendriana (2017: 3) kemampuan dalam belajar matematika diklasifikasikan menjadi beberapa kompetensi utama yaitu pemahaman, komunikasi, pemecahan masalah, penalaran, koneksi, representasi, berpikir kritis, dan berpikir kreatif matematis serta kemampuan matematis lainnya. Sehingga dapat disimpulkan bahwa pemahaman merupakan kemampuan dasar yang harus dimiliki siswa. Pemahaman matematis penting dimiliki siswa karena diperlukan untuk menyelesaikan masalah matematika, masalah dalam disiplin ilmu lain, dan masalah dalam kehidupan sehari-hari Kesumawati (2008). Hal ini menjadi alasan bahwa kemampuan pemahaman matematis siswa sangat perlu untuk dikembangkan agar memudahkan siswa untuk dalam proses pembelajaran.

Berdasarkan hasil observasi yang dilakukan di salah satu Sekolah Menengah Pertama (SMP) di Kabupaten Cirebon dengan sampel sebanyak 39 siswa, masih ditemukan kesulitan-kesulitan yang dialami siswa dalam mengerjakan soal himpunan yang dibuat

Diterbitkan oleh:

Universitas Wiralodra

Jln. Ir. H. Juanda Km 3 Indramayu, Jawa Barat 
berdasarkan indikator-indikator kemampuan pemahaman matematis. Materi himpunan merupakan materi yang mempunyai banyak sub bab, hal ini yang menjadikan siswa merasa kesulitan dalam mempelajari himpunan termasuk materi yang sulit untuk dipelajari siswa. Dalam mempelajari materi himpunan siswa hanya mengandalan hafalan untuk melakukan operasi-operasi himpunan tanpa memahami tahapan-tahapan yang harus dilakukan sehingga siswa kesulitan dalam mempelajari materi himpunan.

Berdasarkan beberapa permasalahan yang telah dipaparkan, peneliti tertarik untuk menganalisis jawaban siswa terkait materi himpunan dengan soal yang dibuat sesuai indikator kemampuan pemahaman matematis, sehingga peneliti mengambil judul "analisis kesulitan siswa dalam mengerjakan soal materi himpunan berbasis kemampuan pemahaman matematis"

\section{Kajian Teori}

Kemampuan pemahaman matematis merupakan kemampuan dasar yang sangat penting dan harus dimiliki siswa dalam belajar. Menurut Putra (2018: 19) menyatakan bahwa kemampuan pemahaman matematis merupakan kemampuan siswa dalam memahami suatu konsep sehingga dapat tercapainya tujuan pembelajaran. Sedangan menurut Rosita (2017: 267), seseorang dikatakan sudah mempunyai kemampuan pemahaman matematis apabila Ia sudah dapat menyatakan atau mengkomunikasikan ideide matematis dalam berbagai bentuk representasi. Dari beberapa pendapat tentang kemampuan pemahaman matematis di atas maka dapat disimpulkan bahwa kemampuan pemahaman matematis adalah kemampuan dasar yang harus dimiliki siswa dalam proses pembelajaran dimana siswa dapat memahami konsep atau ide-ide matematika dan dapat mengkomunikasikan ide-ide yang telah diperoleh dalam berbagai bentuk penyampaian sehingga diharapkan tujuan pembelajaran dapat tercapai.

Siswa yang mempunyai kemampuan pemahaman matematis yang baik, dalam kurikulum 2013 (Hendriana, 2017: 8) menyatakan beberapa indikator kemampuan pemahaman matematis yaitu (a) menyatakan ulang konsep yang telah dipelajar; (b) mengklarifikasi objek-objek berdasarkan dipenuhi tidaknya persyaratan yang membentuk konsep tersebut; (c) mengidentifikasi sifat-sifat operasi atau konsep; (d) menerapkan konsep secara logis; (e) memberikan contoh dari konsep yang dipelajari; (f) menyajikan

Diterbitkan oleh: 
konsep dalam berbagai macam bentuk representasi matematis (tabel, graf, diagram, model matematika atau cara lainnya); (g) mengaitkan berbagai konsep dalam matematika maupun diluar matematika; (h) mengembangkan syarat perlu dan atau syarat cukup suatu konsep. Sedangkan menurut NCTM (Hendriana, 2017: 7) merinci indikator pemahaman matematis yakni (a) mendefinisikan konsep secara verbal dan tulisan; (b) mengidentifikasi dan membuat contoh bukan contoh; (c) menggunakan model, diagram dan simbol-simbol untuk mempresentasikan suatu konsep; (d) mengubah suatu bentuk representasi ke bentuk lainnya; (e) mengenal berbagai makna dan interpretasi konsep; (f) mengidentifikasi sifatsifat suatu konsep dan mengenal syarat (syarat perlu/syarat cukup) yang menentukan suatu konsep; (g) membandingkan dan membedakan konsep-konsep.

Berdasarkan uraian tersebut, peneliti menggunakan tiga indikator kemampuan pemahaman matematis yaitu dua indikator dalam kurkulum 2013 dan satu indikator menurut NCTM. Indikator kemampuan pemahaman matematis yang digunakan adalah (a) mengubah suatu bentuk representasi ke bentuk lainnya; (b) menerapkan konsep secara logis, (c) mengidentifikasi dan membuat contoh dan bukan contoh.

Pada saat kegiatan pembelajaran seringkali masih ditemukan kesulitan belajar yang dialami siswa sehingga menyebabkan tujuan pembelajaran tidak tercapai secara maksimal. Learning obstacle merupakan hambatan belajar atau kesulitan belajar pada saat pembelajaran. Kesalahan yang dapat dilihat dari siswa yaitu pada saat siswa melakukan kesalahan saat diberikan pertanyaan atau soal. Menurut Wahyuni (2017: 5), faktor yang menjadi penghambat dalam belajar yaitu faktor internal dan eksternal. faktor internal adalah hambatan yang berasal dari diri si pembelajar, dan faktor eksternal adalah hambatan yang berasal dari lingkungan sekitar si pembelajar. Hambatan internal adalah faktor-faktor yang menyebabkan belajar merupakan sesuatu yang berat yang berasal dari dalam pembelajar yaitu (1) kondisi psikologis ketika belajar; (2) kejenuhan belajar; (3) tidak merasa senang dengan subjek yang dipelajari; (4) tidak mengetahui manfaat yang dipelajari; (5) Tingkat intelektualitas. Menurut Cornu (Wahyuni, 2017: 6), learning obstacle terbagi menjadi empat, yaitu: (1) hambatan kognitif adalah hambatan yang terjadi pada saat siswa mengalami kesulitan belajar; (2) hambatan genetis dan psikologi adalah hambatan yang terjadi akibat perkembangan pribadi siswa; (3) hambatan didaktis adalah

Diterbitkan oleh: 
hambatan yang terjadi akibat perlakuan proses pembelajaran yang dilakukan oleh guru pada proses pembelajaran; (4) hambatan epistimologis adalah hambatan hambatan yang berkaitan dengan penguasaan konsep matematika. Berbeda dengan Cornu, Brousseau (Suratno, 2009; Maharani, 2014: 477) membagi tiga hambatan belajar siswa (learning obstacle) yaitu hambatan ontogenik adalah Hambatan yang salah satu penyebabnya karena pembatasan konsep pembelajaran pada saat perkembangan anak, hambatan didaktis adalah Hambatan yang berasal dari pemberian konsep yang salah, terjadi akibat dari kekeliruan proses pembelajaran yang berasal dari sistem pembelajaran di sekolah itu sendiri, disebabkan oleh cara guru membuat dan merancang kurikulum untuk pembelajaran, dan hambatan epistimologis adalah Menurut Duroux (Suryadi, 2010) hambatan epistimologis merupakan pengetahuan seseorang yang hanya terbatas pada konteks tertentu atau pemahaman siswa tidak lengkap. Berdasarkan uraian diatas, dapat disimpulkan bahwa learning obstacle merupakan suatu kendala yang menghambat tercapainya tujuan pembelajaran, diakibatkan oleh faktor dalam diri siswa sendiri maupun dari luar diri siswa.

\section{METODE PENELITIAN}

Jenis penelitian yang digunakan adalah penelitian deskriptif kualitatif. Penelitian ini dilaksanakan pada semester genaap tahun ajaran 2018/2019. Pengambilan data penelitian dilaksanakan di SMP Negeri 4 Palimanan. Subjek penelitian adalah siswa SMP Negeri 4 Palimanan kelas VII-A dan VII-B yang terdiri dari 39 siswa. Penelitian ini bertujuan untuk menganalisis kesulitan siswa dalam mengerjakan soal kemampuan pemahaman matematis materi himpunan. Teknik pengumpulan data yang digunakan instrumen soal tes uraian sesuai dengan indikator kemampuan pemahaman matematis. Adapun teknik pengolahan data dalam penelitian ini dilakukan dengan cara menganalisis jawaban siswa dalam mengerjakan soal materi himpunan.

\section{HASIL DAN PEMBAHASAN}

\section{Hasil Penelitian}

Uji coba soal yang telah dilakukan kepada 39 siswa dengan indikator soal kemampuan pemahaman matematis. Soal uji coba yang berjumlah 3 soal dan berbentuk uraian. Hasil uji coba kemudian dianalisis kesalahan jawaban siswa dalam menjawab soal

Diterbitkan oleh: 
kemampuan pemahaman matematis. Berikut ini beberapa kesalahan siswa dalam menjawab soal.

Soal 1

\begin{tabular}{|l|}
\hline Perhatikan himpunan-himpunan berikut: \\
$S=\{$ bilangan cacah kurang dari 10$\}$ \\
$A=\{x 12 \leq x \leq 7, x \in$ bilangan bulat $\}$ \\
$B=\{x 1 x<6, x \in$ bilangan asli $\}$ \\
Gambarlah diagram venn-nya! \\
\hline
\end{tabular}

Soal diatas merupakan soal himpunan dengan indikator kemampuan menggunakan model, diagram, dan simbol-simbol untuk merepresentasikan suatu konsep. Berikut ini salah satu jawaban siswa pada nomor 1 .

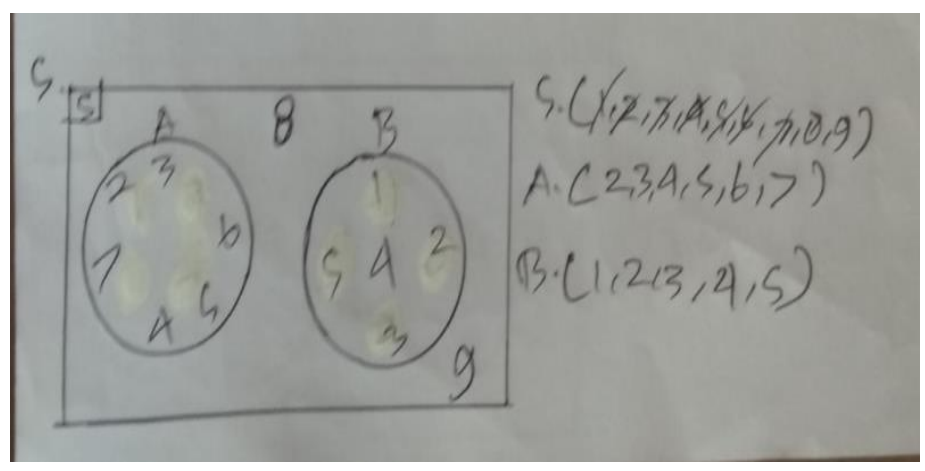

Gambar 1 jawaban siswa

Berdasarkan jawaban siswa pada soal 1 dapat dianalisis learning obstacle siswa bahwa siswa belum memahami penyajian anggota himpunan, belum memahami jenis-jenis bilangan, belum dapat memahami irisan dua himpunan sehingga gambar diagram venn yang dibuat belum tepat

Soal 2

Tentukan apakah kumpulan berikut termasuk himpunan atau bukan himpunan.

Kemudian jika himpunan tentukan tiga anggota himpunannya.

a. Kumpulan buah berwarna merah

b. Kumpulan bunga yang berwarna indah

c. Kumpulan hewan berkaki dua

d. Kumpulan mata pelajaran yang sulit 
Soal diatas termasuk kedalam indikator kemampuan Mengidentifikasi dan membuat contoh dan bukan contoh. Berikut salah satu jawaban siswa yang disajikan pada gambar 2.

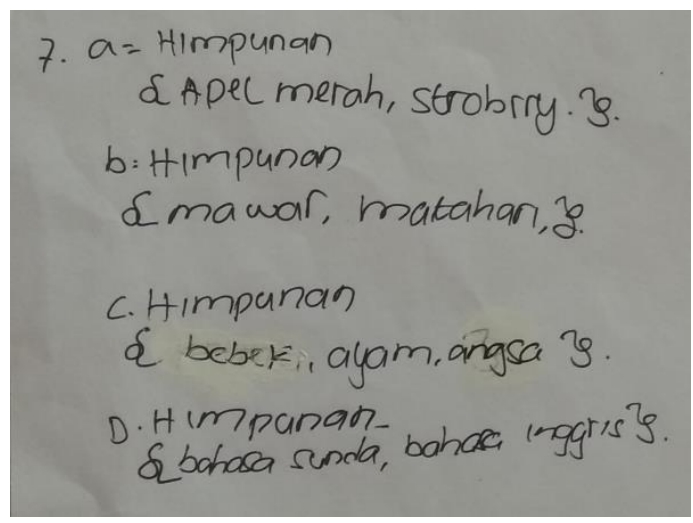

Gambar 2 jawaban siswa

Pada jawaban siswa diatas, learning obstacle yang dialami siswa yaitu siswa tidak memahami konsep himpunan semesta sehingga tidak dapat membedakan kumpulan yang termasuk himpunan dan bukan himpunan.

Soal 3

Dalam suatu kelas terdapat 18 siswa gemar matematika, 15 siswa gemar IPA dan 12 siswa gemar keduanya. Jika 9 siswa tidak gemar keduanya.

a. Gambarkan diagram venn-nya

b. Berapa jumlah siswa yang ada di dalam kelas tersebut?

Soal 3 diatas termasuk indikator kemampuan menerapkan konsep secara logis, dalam soal tersebut siswa diminta untuk Menggambarkan diagram venn dan menerapkan konsep operasi himpunan. Berikut jawaban siswa pada gambar 3.

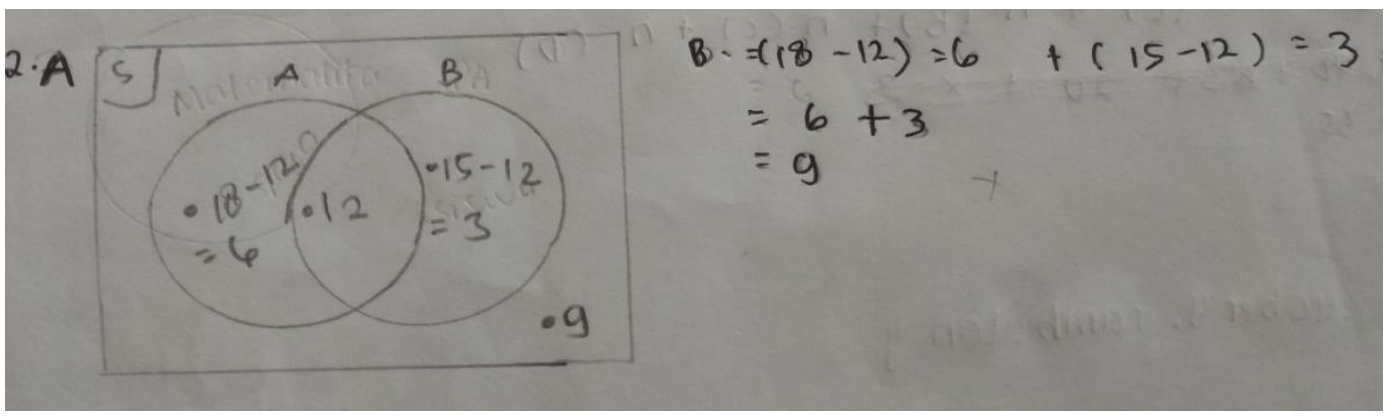

Diterbitkan oleh:

Universitas Wiralodra

Jln. Ir. H. Juanda Km 3 Indramayu, Jawa Barat 
Gambar 3 jawaban siswa

Berdasarkan anaisis jawaban siswa pada poin (a), learning obstacle nya yaitu keliru dalam memberikan noktah sehingga gambar diagram venn nya pu kurang tepat, sedangkan pada poin (b) siswa belum memahami konsep operasi himpunan sehingga tidak dapat menentuka jumlah keseluruhan anggota himpunan.

Persentase learninng obstacle dari 39 siswa dalam mengerjakan soal himpunan berdasarkan indikator kemampuan pemahaman matematis disajikan pada diagram berikut.

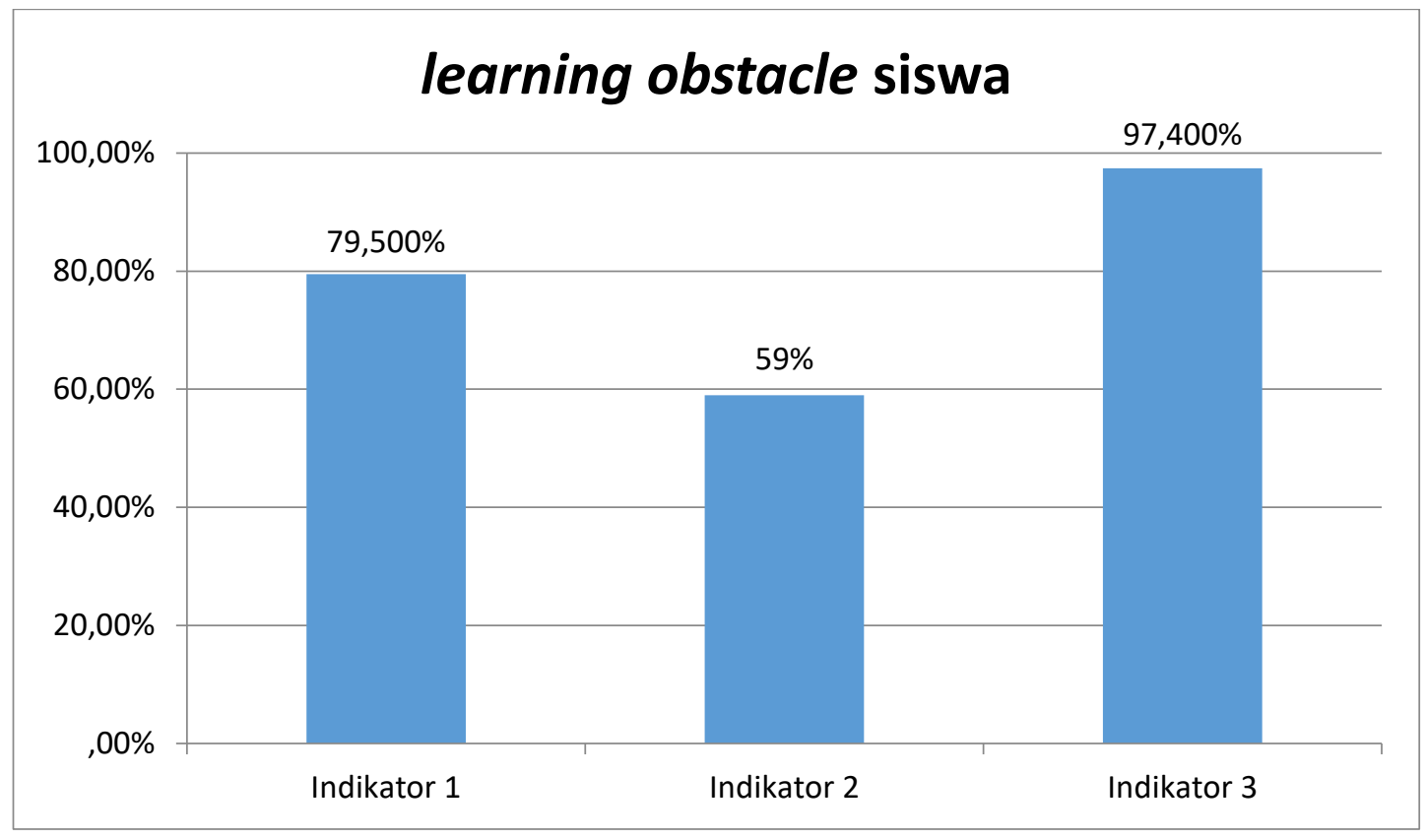

Berdasarkan diagram diatas learning obstacle yang pertama dialami siswa sebesar 97,4\% adalah indikator 3 yaitu kemampuan menerapkan konsep secara logis. Hasil dari jawaban 39 siswa menunjukan bahwa siswa tidak dapat menggambarkan diagram venn dari permasalahan yang disajikan dan belum memahami konsep operasi himpunan. Learning obstacle yang ke-dua sebesar 79,5\% dari 39 jawaban siswa adalah indikator kemampuan menggunakan model, diagram, dan simbol-simbol untuk merepresentasikan suatu konsep. Hasil dari jawaban siswa menunjukan bahwa siswa masih mengalami kesulitan dalam penyaajian anggota himpunan karena siswa belum memahami jenis bilangan dan tanda pertidaksamaan sehingga siswa mengalami kesuliltan dalam menggambarkan diadram venn. learning obstacle yang ke-tiga adalah kemampuan Mengidentifikasi dan membuat contoh dan bukan contoh, Sebesar 59\%, hasil dari jawaban 
siswa adalah siswa masih belum memahami kumpulan yang termasuk himpunan dan kumpulan yang termasuk bukan himpunan.

\section{Pembahasan}

Berdasarkan hasil penelitian dengan menganalisis learning obstacle diperoleh hal yang paling dominan yakni kemampuan menerapkan konsep secara logis. Siswa cenderung belum mampu mengkaitkan satu konsep ke konsep yang lain secara logis. Selain itu siswa mengalami (1) kesulitan dalam menggambar diagram Venn, (2)kesulitan dalam memahami konsep mengoperasikan himpunan, (3) kesulitan dalam hal menggunakan model, diagram, dan simbol-simbol untuk merepresentasikan suatu kemampuan, (4) kesulitan dalam mengidentifikasi dan membuat contoh dan bukan contoh, (5) masih belum memahami kumpulan yang termasuk himpunan dan kumpulan yang termasuk bukan himpunan.

Hal ini sejalan dengan hasil penelitiannya Karunia \& Mulyono (2017) yang menjelaskan bahwa penerapan konsep secara logis bisa dipengaruhi oleh gaya belajar. Siswa yang memiliki gaya belajar kinestetik memiliki kemampuan dalam menyelesaikan masalah secara procedural dan logis. Selain itu berdasarkan hasil penelitiannya Yusuf, Y., Titat \& Yuliawati (2017) mengungkapkan hasil temuannya berkaitan dengan learning obstacle siswa dalam memahami konsep materi statistic secara garis besar mengalami kesulitan belajar. Seperti mengalami ontogenic obstacle, epistemological obstacle dan didactical obstacle. Penelitiannya Asih, Rosita \& Tonah (2018) menyimpulkan bahwa (1) siswa kesulitan dalam mengidentifikasi bentuk limit tak tentu, (2) siswa kesulitan dalam mengaitkan permasalahan dengan konsep lain yang berkaitan, (3) siswa kesulitan dalam membuat model matematika dari soal cerita

\section{SIMPULAN DAN SARAN}

\section{Simpulan}

Berdasarkan analisis data dan pembahasan, maka diperoleh simpulan sebagai berikut. Learning obstacle yang dialami siswa diantaranya siswa tidak dapat menggambarkan diagram venn dari permasalahan yang disajikan dan belum memahami konsep operasi himpunan, siswa masih mengalami kesulitan dalam penyaajian anggota himpunan karena siswa belum memahami jenis bilangan dan tanda pertidaksamaan

Diterbitkan oleh: 
sehingga siswa mengalami kesuliltan dalam menggambarkan diadram venn, siswa masih belum memahami kumpulan yang termasuk himpunan dan kumpulan yang termasuk bukan himpunan.

\section{Saran}

Berdasarkan hasil penelitian yang diperoleh, penulis merasa perlu memberikan beberapa saran berikut.

1. Kemampuan pemahaman matematis adalah kemampuan yang harus dimiliki siswa, maka guru hendaknya meningkatkan kemampuan pemahaman matematis siswa

2. Subjek penelitian ini hanya kelas VIII B SMPN 4 Palimanan, maka disarankan untuk penelitian selanjutnya.

\section{DAFTAR PUSTAKA}

Asih, K. S., Rosita, C. D., \& Tonah, T. (2018). Analisis Learning Obstacles Pada Pokok Bahasan Aplikasi Turunan Pada Siswa Kelas XI SMA. In Prosiding Seminar Nasional Matematika dan Pendidikan Matematika (SNMPM) (Vol. 2, No. 1, pp. 211221).

Hendriana, H., Rohaeti, E. E., \& Sumarmo, U. (2017). Hard Skills Dan Soft Skills Matematik siswa. Bandung: PT Refika Aditama.

Kesumawati, N. (2008). Pemahaman Konsep Matematik dalam Pembelajaran Matematika. Semnas Matematika dan Pendidikan Matematika, 2, 231-234.

Karunia, E. P., \& Mulyono, M. (2017). Analisis Kemampuan Pemahaman Konsep Siswa Kelas VII Berdasarkan Gaya Belajar dalam Model Knisley. In PRISMA, Prosiding Seminar Nasional Matematika (pp. 337-346).

Maharani, A. Ferdianto, F. \& Setiyani. (2014). Analisis hambatan belajar (Learning Obstacle) Pada Mata Kuliah Kalkulus. Seminar Nasional Pendidikan Matematika Ahmad Dahlan. ISSN: 9772407749004.

Muhardi, M. (2004). Kontribusi pendidikan dalam meningkatkan kualitas bangsa Indonesia. MIMBAR, Jurnal Sosial dan Pembangunan, Vol 20, No 4, Hal 478-492.

Putra, D, P, dkk. (2018). Kemampuan Pemahaman Matematis Siswa SMP di Bandung Barat. JPPM (Jurnal Pendidikan dan Pembedayaan Masyarakat), Vol. 11, No. 1, 2018.

Diterbitkan oleh: 
Rosita, D, C, dkk. (2017). Bahan Ajar Aljabar Linear Berbasis Kemampuan Pemahaman Matematis. Unnes Journal of Mathematics Education Research, Vol 6, No 2, Hal $266-272,2017$.

Sariningsih, R. (2014). Pendekatan Kontekstual Untuk Meningkatkan Kemampuan Pemahaman Matematis Siswa SMP. Jurnal Ilmiah Program Studi Matematika. Vol 3, No 2, Hal 150-163.

Sudirman (2016). Analisis Pemahaman Konsep Himpunan Mahasiswa Ditinjau dari Asal Sekolah. Mathline: Jurnal Matematika dan Pendidikan Matematika, Vol 1, No 1, 2016.

Sundayana, R. (2014). Media dan Alat Peraga dalam Pembelajaran Matematika. Bandung: Alfabeta.

Wahyuni, A. (2017). Analisis Hambatan Belajar Mahasiswa pada Mata Kuliah Kalkulus Dasar. JNPM (Jurnal Nasional Pendidikan Matematika) Maret 2017, Vol. 1, No. 1, hal.10-23.

Yusuf, Y., Titat, N., \& Yuliawati, T. (2017). Analisis Hambatan Belajar (Learning Obstacle) Siswa SMP Pada Materi Statistika. AKSIOMA: Jurnal Matematika dan Pendidikan Matematika, Vol 8, No 1, Hal 76-86. 